\title{
GnRH in the male dog: dose-response relationships with LH and testosterone
}

\author{
B. W. Knol ${ }^{1 *}$, S. J. Dieleman ${ }^{2}$, M. M. Bevers ${ }^{2}$ and \\ W. E. van den Brom ${ }^{1}$ \\ ${ }^{1}$ Department of Clinical Sciences of Companion Animals; and ${ }^{2}$ Department of Herd Health and \\ Reproduction, Faculty of Veterinary Medicine, University of Utrecht, Yalelaan 8, PO Box 80.154, \\ 3508 TD Utrecht, The Netherlands
}

\begin{abstract}
Dose-response relationships between $\mathrm{GnRH}$ and $\mathrm{LH}$, and between $\mathrm{GnRH}$ and testosterone, were investigated in six male dogs by intravenous administration of a $\mathrm{GnRH}$ analogue at different doses. Each dose of $\mathrm{GnRH}$ analogue induced an immediate rise in the plasma concentration of LH and then a rise in plasma testosterone concentration. Irrespective of the dose used, the rise in testosterone began $10 \mathrm{~min}$ after the $\mathrm{GnRH}$ injection. Administration of $\mathrm{GnRH}$ at doses of $0.01,0.1,1,10$ and $100 \mu \mathrm{g} \mathrm{kg}^{-1}$ resulted in maximum LH concentrations in plasma (mean $\pm \mathrm{SEM} ; n=6$ ) of $22 \pm 7,27 \pm 6,40 \pm 7,57 \pm 13$ and $56 \pm 10 \mu \mathrm{g} \mathrm{l}^{-1}$, respectively. These doses induced maximum concentrations of testosterone in plasma (mean $\pm \operatorname{SEM} ; n=6$ ) of $16 \pm 4,20 \pm 4,22 \pm 3,22 \pm 4$ and $24 \pm 7 \mathrm{nmol} \mathrm{l}^{-1}$, respectively. The lag time between peak concentrations of $\mathrm{LH}$ and testosterone varied from 35 to $55 \mathrm{~min}$. The calculated maximum response of testosterone to $\mathrm{LH}$, secreted by the anterior pituitary after $\mathrm{GnRH}$ injection, was 1.8 times higher than to $\mathrm{GnRH}$. It was concluded that intravenous administration of $\mathrm{GnRH}$ induced marked and dose-dependent increases in plasma concentrations of $\mathrm{LH}$ and testosterone, and that there does not appear to be a direct effect of GnRH on Leydig cells in male dogs.
\end{abstract}

\section{Introduction}

The hypothalamus-pituitary-adrenocortical (HPA) axis has been studied extensively in dogs (Kemppainen et al., 1986; Middleton et al., 1987; Mol and Rijnberk, 1989). Data on the hypothalamus-pituitary-testis (HPT) axis in the dog, however, are scarce (Falvo and Vincent, 1980; Falvo et al., 1980). In male dogs a linear trend in LH responses was observed after intravenous administration of $\mathrm{GnRH}$ at doses varying from 0.005 to $0.25 \mathrm{\mu g} \mathrm{kg}^{-1}$ (Falvo et al., 1982), but, to our knowledge, there are no reports on dose-response relationships between $\mathrm{GnRH}$ and $\mathrm{LH}$ and testosterone in males of any species.

The present study was undertaken to characterize pituitary and testicular responses to intravenous administration of a GnRH analogue in dogs.

\section{Materials and Methods}

\section{Animals}

Six healthy adult male beagles, $6.3 \pm 2.6$ (mean \pm SD) years of age and weighing $14.5 \pm 2.3 \mathrm{~kg}$, were used in this study. Palpation of the testes of each dog revealed no abnormalities.

"Correspondence.

Received 12 June 1992
The animals were housed individually in indoor kennels with access to separate outdoor runs for about $2 \mathrm{~h}$ per day, and were exposed to a normal daylight regimen (the experiment was performed in September and October). The dogs were fed a standard commercial diet in the morning and water was always available. Because their fertility was studied simultaneously, the dogs were accustomed to twice weekly semen collection by manual manipulation in the presence of a bitch in oestrus. Intervals between $\mathrm{GnRH}$ administration and semen collection, and vice versa, were at least $24 \mathrm{~h}$.

\section{Experimental design}

Each dog was treated with a GnRH analogue (Fertagyl: Intervet International BV, Boxmeer) containing $0.1 \mathrm{mg}$ gonadorelin $\mathrm{ml}^{-1}$. Six doses $\left(0,0.01,0.1,1,10\right.$ and $100 \mu \mathrm{g} \mathrm{kg}^{-1}$ body weight $)$ were used in a $6 \times 6$ Latin square design (Spriet and Simon, 1985). All dogs were injected via the cephalic vein with either $\mathrm{GnRH}$ diluted in a solution of $9 \mathrm{~g} \mathrm{NaCl} l^{-1}$ or an equal volume of diluent only (controls). Treatments were given at weekly intervals.

Starting at 08:00 h, blood samples were collected at -20 , $-10,0,5,10$ and at $10 \mathrm{~min}$ intervals until $160 \mathrm{~min}$ after injection of $\mathrm{GnRH}$. Blood was collected by jugular venepuncture into sterile $5 \mathrm{ml}$ heparinized tubes (Vacutainer; Becton-Dickinson, Etten-Leur), which were immediately placed on ice until centrifugation $\left(10 \mathrm{~min}, 1600 \mathrm{~g}\right.$ ) at $4^{\circ} \mathrm{C}$ within $30 \mathrm{~min}$. Plasma was stored at $-25^{\circ} \mathrm{C}$ until assayed. 


\section{Hormone deferminations}

Plasma LH concentrations were assessed by a heterologous radioimmunoassay as described by Nett et al. (1975). The sheep antibody, CSU-204 (kindly supplied by G.D. Niswender, Colorado State University), radioiodinated NIAMDD-bLH-4 and canine pituitary standard LER 1685-I were used in this assay.

Plasma testosterone concentrations were measured by radioimmunoassay after extraction according to the method of Dieleman et al. (1983). Validation of this RIA method in dog plasma produced intra- and interassay coefficients of variation of 12 and $14 \%$, respectively; the sensitivity was $0.35 \mathrm{nmol} \mathrm{l}^{-1}$.

\section{Statistical analysis and calculations}

Pretreatment plasma values were calculated separately for each dose of $\mathrm{GnRH}$, except the control dose, by averaging the plasma values obtained at $-20,-10$ and $0 \mathrm{~min}$ in the six dogs. Each of the five pretreatment values was tested with a paired $t$ test against the corresponding plasma value at $160 \mathrm{~min}$ to determine whether plasma hormone concentrations had returned to baseline values within $160 \mathrm{~min}$ after injection.

A response was defined as the total area under the curve corresponding to a certain dose of GnRH. This area was calculated geometrically by computer for each response of $\mathrm{LH}$ or testosterone from the time of $\mathrm{GnRH}$ injection until $160 \mathrm{~min}$ thereafter, and was corrected for the area under the control curve. Dose-response relationships were calculated on the basis of reciprocal response versus reciprocal dose according to the method of least squares regression (Snedecor and Cochran, 1980). The maximum response was derived from the intercept of the regression equation. Coefficients of correlation were tested for significance by a one-tail test. The level of significance was $P \leqslant 0.05$.

\section{Results}

No adverse effects of $\mathrm{GnRH}$ administration on health or behaviour were observed in any of the dogs. Pretreatment plasma concentrations (mean \pm SEM; $n=30$ ) were $4.6 \pm 0.5 \mu \mathrm{g} \mathrm{l}^{-1}$ for $\mathrm{LH}$ and $9.7 \pm 1.7 \mathrm{nmol}^{-1}$ for testosterone. Plasma concentrations (mean \pm SEM; $n=30$ ) determined at $160 \mathrm{~min}$ were $3.9 \pm$ $0.4 \mu \mathrm{g}^{-1}$ for $\mathrm{LH}$ and $7.1 \pm 1.3 \mathrm{nmol} \mathrm{I}^{-1}$ for testosterone (Fig. 1). There were no significant differences in $\mathrm{LH}$ or testosterone between the mean pretreatment value and mean value obtained at $160 \mathrm{~min}$, nor among the five pretreatment values, nor among the five values obtained at $160 \mathrm{~min}$.

Each GnRH dose induced an immediate increase in the plasma concentration of $\mathrm{LH}$ and then an increase in concentration of testosterone in plasma (Fig. 1). Irrespective of dose, the increase in testosterone began $10 \mathrm{~min}$ after $\mathrm{GnRH}$ injection. Administration of GnRH at doses of $0.01,0.1$ and $1 \mu \mathrm{g} \mathrm{kg}^{-1}$ resulted in maximum concentrations of LH in plasma (mean \pm SEM; $n=6$ ) at 5 min after injection of $22 \pm 7$, $27 \pm 6$ and $40 \pm 7 \mu \mathrm{g}^{-1}$, respectively. The GnRH doses of 10 and $100 \mu \mathrm{g} \mathrm{kg}^{-1}$ resulted in mean maximum LH concentrations at 10 and $20 \mathrm{~min}$ after injection of $57 \pm 13$ and $56 \pm 10 \mu \mathrm{g} \mathrm{l}^{-1}$, respectively. Maximum plasma testosterone concentrations (mean \pm SEM; $n=6$ ) induced by GnRH doses
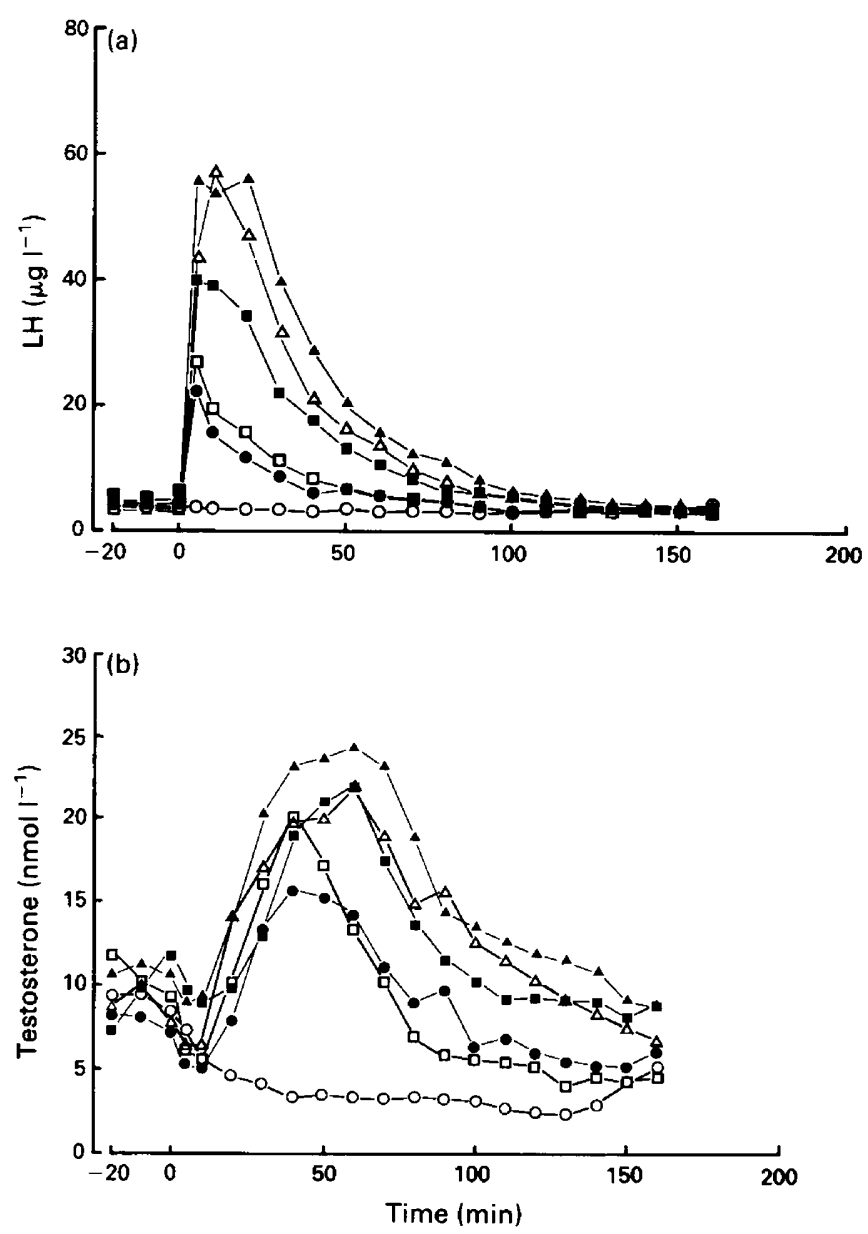

Fig. 1. Mean responses of (a) LH and (b) testosterone to six doses of a $\mathrm{GnRH}$ analogue in six male dogs; $(\bigcirc)$ controls, (O) $0.01 \mu \mathrm{g} \mathrm{kg}^{-1},(\square)$

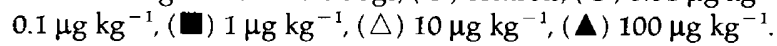

of 0.01 and $0.1 \mu \mathrm{g} \mathrm{kg}^{-1}$ at $40 \mathrm{~min}$ after injection were $16 \pm 4$ and $20 \pm 4 \mathrm{nmol}^{-1}$, respectively. The GnRH doses of 1 , 10 and $100 \mu \mathrm{g} \mathrm{kg}^{-1}$ resulted in mean maximum concentrations of testosterone in plasma at $60 \mathrm{~min}$ after injection of $22 \pm 3$, $22 \pm 4$, and $24 \pm 7 \mathrm{nmol} 1^{-1}$, respectively. The lag time between $\mathrm{LH}$ and testosterone peaks varied from 35 to $55 \mathrm{~min}$.

The responses of $\mathrm{LH}$ and testosterone to $\mathrm{GnRH}$ administration are shown as a function of the logarithm of the GnRH dose (Fig. 2). The corresponding regression equations for reciprocal dose versus reciprocal response were $Y \times 10^{4}=$ $0.15 X+8.10(r=0.80 ; P=0.05 ; n=5)$ and $Y \times 10^{4}=$ $0.05 X+7.50(r=0.64 ; n=5)$, respectively. Similarly, the reciprocal dose-response relationship between $\mathrm{LH}$ and testosterone was $Y=0.38 X+0.00042(r=0.97 ; P<0.005$; $n=5$ ). The calculated maximum response of testosterone to $\mathrm{LH}$, secreted by the anterior pituitary after $\mathrm{GnRH}$ injection, was 1.8 times higher than to $\mathrm{GnRH}$.

\section{Discussion}

In this experiment in male dogs, single intravenous injections of a $\mathrm{GnRH}$ analogue resulted in a dose-dependent increase in 

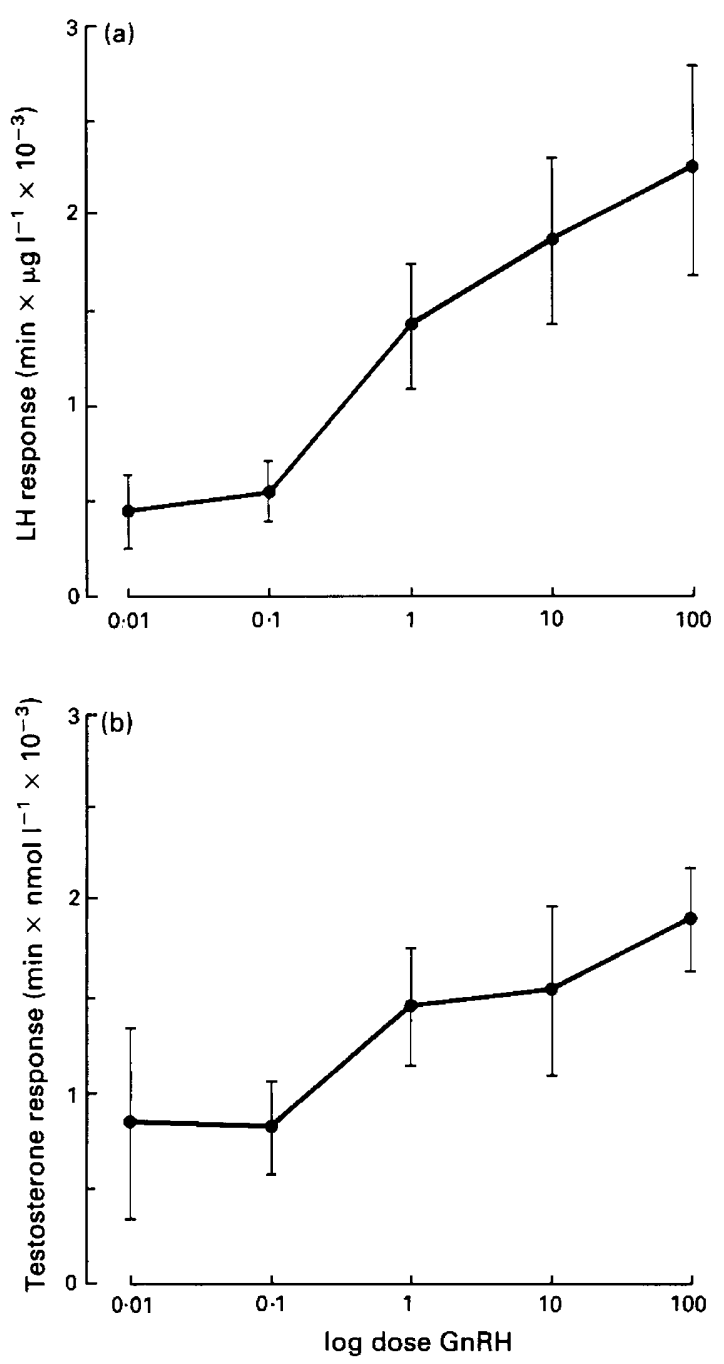

Fig. 2. Responses (mean \pm SEM) of (a) LH and (b) testosterone to intravenous administration of five doses of a $\mathrm{GnRH}$ analogue in six male dogs.

plasma concentrations of both $\mathrm{LH}$ and testosterone. A dose of $0.01 \mu \mathrm{g} \mathrm{GnRH} \mathrm{kg}{ }^{-1}$ induced an LH response of $22 \mu \mathrm{g} \mathrm{l}^{-1}$. This response is similar to that assessed in another study in male dogs (Falvo et al., 1980), in which intravenous administration of $0.25 \mu \mathrm{g} \mathrm{GnRH} \mathrm{kg}{ }^{-1}$ resulted in an LH response of $21 \mu \mathrm{g} \mathrm{l}^{-1}$.

Significant relationships were found between GnRH dose and $\mathrm{LH}$ response as well as between $\mathrm{LH}$ dose, being the $\mathrm{LH}$ response to $\mathrm{GnRH}$, and testosterone response, but not between $\mathrm{GnRH}$ dose and testosterone response. These findings suggest that Leydig cells were activated by LH released after GnRH injection rather than by the GnRH injected. This is substantiated by the fact that the calculated maximum response of testosterone to LH was 1.8 times higher than the calculated maximum response of testosterone to GnRH. Further calculations show that the maximum response of $\mathrm{LH}$ to $\mathrm{GnRH}$ is $0.12 \times 10^{4}\left(\min \times \mu \mathrm{g} \mathrm{l}^{-1}\right)$. Substitution of this value in the dose-response relationship of $\mathrm{LH}$ and testosterone produces a response of $0.13 \times 10^{4}\left(\mathrm{~min} \times \mu \mathrm{g} \mathrm{l}^{-1}\right)$, which equals the maximum response of testosterone to $\mathrm{GnRH}$. It can therefore be concluded that direct effects of GnRH on Leydig cells which have been documented in rats (Clayton et al., 1985) appear to be absent in dogs as they are in rams (Meijer et al., 1989).

In summary, we found that intravenous administration of a $\mathrm{GnRH}$ agonist induced distinct and dose-dependent increases in plasma LH as well as testosterone concentrations, and that there appears to be no direct effect of $\mathrm{GnRH}$ on Leydig cells in male dogs.

The authors thank D. M. Blankenstein, A. V. P. van de Poll, and H. T. M. van Tol for measuring plasma hormone concentrations, and J. Fama, H. G. M. van Engelen, E. M. G. Senders, M. J. Pel, L. Alflen and $Y$. Ouborg for their assistance in performing the experiments.

\section{References}

Clayton RN, Detta A, Nikula H and Huhtaniemi IT (1985) Physiological role of putative testicular gonadotrophin releasing hormone (GnRH) Medical Biology $63201-209$

Dieleman SJ, Kruip ThAM, Fontijne P, De Jong WHR and Van der Weyden GC (1983) Changes in oestradiol, progesterone, and testosterone concentrations in follicular fluid and in the micromorphology of preovulatory bovine follicles relative to the peak of luteinizing hormone Journal of Endocrinology 97 $31-42$

Falvo RE and Vincent DL (1980) Testosterone regulation of follicle-stimulating hormone secretion in the male dog Journal of Andrology 1 197-201

Falvo RE, DePalatis LR, Moore T, Kepic TA and Miller J (1980) Annual variations in plasma levels of testosterone and luteinizing hormone in the laboratory male mongrel dog Joumal of Endocrinology 86 425-430

Falvo RE, Gerrity M, Pirmann J, Winter M, Vincent DL and Miller J (1982) Testosterone pretreatment and the response of pituitary LH to gonadotropinreleasing hormone ( $\mathrm{GnRH})$ in the male dog Journal of Andrology 3 193-198

Kemppainen RJ, Filer DV, Sartin JL and Reed RB (1986) Ovine corticotrophinreleasing factor in dogs: dose-response relationships and effects of dexamethasone Acta Endocrinologica 112 12-19

Meijer JC, Trudeau VL, De Jong FH, Bevers M, Noordhuizen-Stassen EN and Wensing CJG (1989) Absence of direct effects of GnRH on testicular steroid secretion in the ram Journal of Reproduction and Fertility 86 517-524

Middleton DJ, Rijnberk A, Bevers MM, Goos HJTh, Beeftink EA, Thijssen JHH and Croughs RJM (1987) Some functional and morphologic aspects of canine corticotrophs Frontiers of Hormone Research 17 11-17

Mol JA and Rijnberk A (1989) Pituitary function. In Clinical Biochemistry in Domestic Animals (4th Edn) pp 576-609 Ed. JJ Kaneko. Academic Press, New York

Nett TM, Akbar AM, Phemister RD, Holst PA, Reichert LE Jr and Niswender GD (1975) Levels of luteinizing hormone, estradiol and progesterone in serum during the estrous cycle and pregnancy in the beagle bitch Proceedings of the Society of Experimental Biology and Medicine 148 136-139

Snedecor GW and Cochran WG (1980) Statistical Methods. Iowa State University Press, Ames

Spriet A and Simon P (1985) Experimental designs. In Methodology of Clinical Drug Trials pp 102-110. Karger, Basle 